\title{
Web-Based Course Delivery Approach in Teaching Mass Communication Courses
}

\author{
Shujun Jiang and Ali Rafeeq
}

\begin{abstract}
This paper explores how the changing education technology and learning environment in the digital era are transforming the traditional teaching and learning experience. Based on TPACK model, a combination of technological, pedagogical and content knowledge strategy is adopted. Different course delivery platforms were introduced and their advantages and disadvantages were discussed. Examples of courses developed and delivered through website builders and blogs are showcased on how web-based course delivery approach can enhance teaching and learning experience in media and journalism courses.
\end{abstract}

Index Terms-TPACK, course delivery, websites, blogs, education technology.

\section{INTRODUCTION}

Smart teaching and learning is an evolutionary and innovative process of education technology and approach in response to the changing technology and learning environment in the digital age. Koehler and Mishra [1] developed the Technological Pedagogical Content Knowledge (TPACK) framework to describe the kinds of knowledge needed by an instructor for effective technology integration (Fig. 1). TPACK is a framework that encompasses how the connections among instructors' understanding of content, pedagogy, and technology interact with one another to produce effective teaching [2], [3]. Accordingly, a new TPACK-based definition of smart teaching is introduced, which defines smart teaching as the instructor's knowledge that integrates pedagogical reasoning with what the instructor knows about his/her subject area, combined with an understanding of what smart technology can be used to support teaching and learning objectives. The concept of smart teaching encapsulates teaching and learning approaches that benefit from the use of smart technologies [4].

In mass communication education, the nature of many courses is practically oriented, usually taught with a combination of lectures and tutorials and have to be learned through hands-on projects. Given the availability of new education technology today, course delivery approaches in mass communication, are now undergoing a transformation. Besides traditional face to face course delivery methods, online platforms, used by both teachers and students, can provide everything needed in teaching and learning: e.g. course description/syllabus, announcements, assessments

Manuscript received September 12, 2017; revised November 25, 2017.

The authors are with United Arab Emirates University/Mass Communication Department, Al Ain, UAE (e-mail: Shujun.jiang@uaeu.ac.ae, alirafeeq@uaeu.ac.ae). and their dates and rubrics, weekly topics, additional resources and practice, and etc. [5]. As an integrating part of teaching and learning, the new web-based course delivery platforms can greatly facilitate and enhance teaching and learning experience. Today, popular course delivery options including the following:

1) Learning Management System (LMS) such as Blackboard, Moodle, Schoology.

2) iTunes U;

3) Websites and blogs: WordPress, Wix, Weebly, ...;

4) Additional apps and sites (such as Google Drive Apps, Kahoot.it, Quizlet, Polldaddy, etc.).

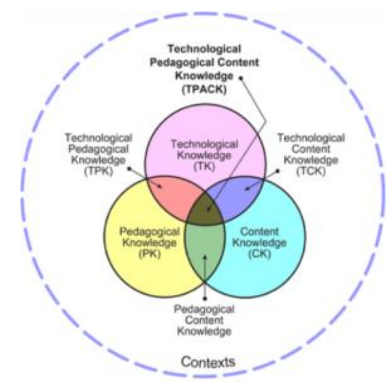

Fig. 1. TPACK framework (Koehler \& Mishra, 2009).

Below are advantages and disadvantages of these course delivery platforms:

TABLE I: LMS -BLACKBOARD

\begin{tabular}{|c|c|}
\hline Advantages & Disadvantages \\
\hline $\begin{array}{l}\text { - Everyone has it } \\
\text { - Works on any device } \\
\text { - University supports it } \\
\text { - Training available } \\
\text { - Best variety of features } \\
\text { - You may already have course } \\
\text { - } \text { material on it } \\
\text { - Students already enrolled }\end{array}$ & $\begin{array}{l}\text { - Students unlikely to visit } \\
\text { recreationally } \\
\text { - Sign in required } \\
\text { - Training needed for advanced } \\
\text { features } \\
\text { - Some features work on the } \\
\text { iPad, others don't }\end{array}$ \\
\hline
\end{tabular}

\begin{tabular}{|l|l|}
\multicolumn{2}{|c|}{ TABLE II: ITUNES U } \\
\hline \multicolumn{1}{|c|}{ Advantages } & \multicolumn{1}{c|}{ Disadvantages } \\
\hline - Best way to deliver an iBook & - Very few features \\
- Looks great on the iPad & - Every person in the class \\
- Easy for students to enroll & has to have an iPad \\
- Collaboration and sharing are easy & - Students must enroll \\
- Nice notes feature for videos and & - Limit of 50 students in \\
iBooks & private courses \\
\hline
\end{tabular}

The factors in choosing the appropriate platform depend on the three areas of knowledge illustrated in TPACK framework: technological, pedagogical and content. Technologically, the availability of devices and facilities, feature of the platform, and ease of use are key factors for adoption. Pedagogically, the function of the platform that can serve specific teaching methods and purposes, e.g. hands-on tutorials, group discussions, project-based learning, flipped-classroom, and other $21^{\text {st }}$-century pedagogy are the 
main concerns. Content-wise, some courses like media and journalism courses that are based more on multi-media content and interactivity of the platform have a higher demand and can benefit more from such applications than other courses.

TABLE III: WEBSITES AND BLOGS

\begin{tabular}{|l|l|}
\hline \multicolumn{1}{|c|}{ Advantages } & \multicolumn{1}{|c|}{ Disadvantages } \\
\hline - All in one & - Privacy \\
- Attractive & - Unofficial \\
- Compatible to other platforms: & - Copyright \\
YouTube, Google docs, Ted & \\
talks... & \\
- No sign in & \\
- No enrollment & \\
- Not term specific & \\
- Encourage recreational study & \\
- Easy to share and showcase & \\
\hline
\end{tabular}

\section{Limitations OF TRADitional COURSE DELIVERY APPROACH IN TEACHING MASS COMMUNICATION COURSES}

The traditional way of teaching practical courses in media and journalism is mainly based on PowerPoint slides and in-class tutorials. There are a couple of problems facing current teaching and learning approaches:

1) A lot of multimedia content cannot be nicely presented, maintained and updated for the instructor and the students.

2) Tutorial instructions can only be delivered in class but not outside class, which is not good for students who forget the procedures after class.

3) Students' presentations, designs, and projects cannot be recorded and shared and showcased.

4) Evaluation of student works is not convenient for emails and Blackboard uploads and downloads.

5) Project sign up is not convenient as we use a paper-based sign-up system, the students cannot switch date, they cannot change their digital tools, and they cannot check out the date easily can have a record of all the tools that are introduced in the class.

6) Traditional class discussions are not so personal and in-depth and also cannot be recorded.

7) Blackboard is designed only for one semester, not for the course, therefore lacks a historical record which can be shown to future students.

\section{WEB-BASED COURSE DELIVERY APPROACHES}

\section{A. Transformation Platforms}

TABLE IV: TRANSFORMATION PLATFORMS

\begin{tabular}{|l|l|}
\hline \multicolumn{1}{|c|}{ Modules } & \multicolumn{1}{c|}{ Platforms } \\
\hline Course delivery & Website builders and blogs: e.g. WordPress \\
\hline Assignments & $\begin{array}{l}\text { Website builders, Blackboard, Quizlet, } \\
\text { Kahoot }\end{array}$ \\
\hline Assessment & $\begin{array}{l}\text { Polldadddy, Google Forms, Websites, } \\
\text { Blackboard }\end{array}$ \\
\hline Discussion & Google Drive Apps: Docs, Forms, Sheets \\
\hline Student Project & $\begin{array}{l}\text { Website builders, Design apps, Google Drive } \\
\text { Apps, Social Media, YouTube }\end{array}$ \\
\hline Tutorials & YouTube, Jing, Screencast-O-Matic \\
\hline Presentations & $\begin{array}{l}\text { Design Apps and Digital tools initiated by } \\
\text { students }\end{array}$ \\
\hline
\end{tabular}

\section{B. Applications and Cost}

- Website builders: Course websites can be created from online website builders such as Wix, Webs, Weebly, WordPress, RAWfolio, jimdo, Sq uareSpace, Google Sites, GoDaddy.

- This course will mainly use WordPress, as it is most compatible with other platforms, such as YouTube, Google Drive, Polldaddy etc. It is free as long as using sub domain name from the website builders. But if more functions are needed, then subscription is required.

- Google Drive Apps: Docs, Sheets, Forms (Free), Google Fusion Table, Google Maps

- Pollydaddy: Free

- Quizlet: Free

- Kahoot: Free

- Screencast Apps: Jing, Screencast-o-matic (both free for limited time)

\section{Content Delivery Strategies}

Course content is mainly delivered through course website and blog updates created from wordpress.com. As course activities are divided into the following two sections, various course delivery approaches are being applied accordingly:

1) Lecture sections: course material will be delivered mainly through blog updates on the course website. Each blog update is one lecture topic containing well-designed multimedia content, e.g. picture slides, videos, PPT slides, links, etc.

2) Tutorials sections: a separate category will be created to deliver the tutorial topics, instructional videos and PPT slides, reference videos from other sources such as YouTube, Lynda.com, etc. Each tutorial project requirements and steps are explained with sample student works showcased. Screencast tools such as Screencast-o-Matic, Jing, will be used for creating screencast tutorials.

Course syllabus, course materials, announcements and other resources are downloadable from the website.

Discussions and project sign-up can be conducted through Google Sheet/Form links posted on the blog updates.

Student presentations can be delivered through applications from their mobile devices e.g. smartphones or iPad, or laptops connecting to the smartboard. A separate category on the website will be created to collect all the tools that are presented by the students, so it can be shared and enjoyed by more students.

Students projects are exhibited through their personal websites created on website builders such as wix.com, webs.com etc. with all course projects and assignments included will be showcased on the course website. This will be a very efficient way for course assessments and also be used as examples for future students.

For assignments and assessments: Polldaddy can be used for creating exams and quizzes. Quizlet can be used to design flashcards and games for the students to understand some basic concepts and theories. Blackboard can be used alongside with websites and blogs for assessments and evaluation.

\section{Showcase of Course Examples}


- Designing

Media

https://designingmediamessages.wordpress.com/

This course is a media design course and is delivered through lectures and tutorials. The students conducted lots of projects using various programs. The website provides class lectures, course material, tutorials/project requirements and instructions, and students' projects showcase. Multimedia content, tutorial videos and hyperlinks for assessment and discussion can be easily integrated on one platform. Flipped classroom approach is applicable.

- Computer Assisted

https://carmsc401.wordpress.com

This course is a journalism course on how to use digital tools in news reporting. Using the website, course content and materials can be easily and beautifully presented. The students can find all resources including course outline, lecture notes, projects instructions, and tutorials on the website. Students projects can also be easily showcased. The website is also compatible with all digital devices, including smartphones, iPad, and computers. Using websites for these practical mass communication courses can greatly enhance teaching and learning experience.

\section{IMPLEMENTING SMART LEARNING PEDAGOGY}

The web-based course delivery approaches [6], [7] implement $21^{\text {st }}$-century smart learning pedagogy as explained below.

Active Learning is a process whereby students use smart devices to engage in activities, such as reading, writing, discussion, or problem-solving that promote analysis, synthesis, and evaluation of class content. From the multimedia content provided on the website, students are more active in thinking, discussion, exploration, researching and problem-solving.

Inquiry-based learning, where smart learning is used in building knowledge from experience and process, especially socially based experience. Students learn through examples of designs, photos, videos, online discussion questions, and projects.

Problem-based learning, where smart devices are used to facilitate learner-centered pedagogy in which learners learn about a subject through the experience of problem-solving. The students are given essay topics, design projects, tutorial assignments, presentations to apply the theoretical concepts, learn and challenge themselves with new tools, skills, and technologies and solve many design problems.

Project-based learning, where learners utilize smart devices to gain knowledge and skills by working for an extended period of time to investigate and respond to a complex question, problem, or challenge. Students need to build their own websites and create blog posts for their media production projects.

Flipped classroom is a pedagogical approach in which direct instruction moves from the group learning space to the individual learning space, and the resulting group space is transformed into a dynamic, interactive learning environment where the educator guides students as they apply concepts and engage creatively in the subject matter. Flipped classroom teaching approach can be well implemented given all the course materials, tutorial instructions and project requirements available on the course website. The students can preview the course content and get well prepared before coming to the class. They can directly work on their tutorials assignments and bring in questions for their individual projects during class time and the instructor can, therefore, provide one on one instruction and assistance.

Behavioral learning, where feedback and reinforcement can be facilitated by smart devices. Given the easy access to the course websites and shared Google Sheets, students' progress of projects and presentation can be well monitored by the instructor, therefore, feedback can be provided timely and instantly. The communication between the instructor and the students can happen anywhere anytime and will no longer be limited to the class time. Polldaddy.com allows the students to view the correct answer right after they finish, which gives students immediate feedback on how they perform and why.

Constructive learning, where concepts and knowledge are built using smart devices when learners are engaged in the social and physical space with others. It is a student-driven process in which learners develop, or construct, their understanding of information as they work with concepts and think about their processes. Learners incorporate their own outside experiences and perspectives as well as those of other students to develop their own understanding of concepts. The shared Google Sheets on the course websites and the students' works exhibited on their personal websites contribute a lot to the constructive learning. In this course, students have the opportunity to share and teach the whole class the digital tools and applications that they are familiar with. They made presentations in the class, post the links to resources and tools on shared Google Sheets and upload their presentation video clips or PPT slides on their personal website. This project offers the whole class to be familiar with a variety of easy to use design tools and applications. Learning happens not only from the instructor to the students, it can be the other way round and it can be between the students as well. On the other hand, when students post each of their projects on their personal website, which can also be accessed by other students, facilitates peer competition, peer assessment and more often peer learning. Talented and experienced students can be easily discovered and contribute to helping other students.

Context-based learning, when learners take a smart device into an educationally relevant real-world location and learn from that particular context. Students can easily access the course website with their smartphones wherever they go. They can check out the theories, concepts, and practical procedures whether they are viewing and analyzing a design in real life or doing design projects. Applications presented by students on their smartphones allow them to make sketches, scans, photos and designs for their real-life projects.

Co-operative learning, where smart devices are used to organize classroom activities into academic and social learning experiences. It is the instructional use of small groups so that students work together to maximize their own and each other's learning. The course website provides a good platform for co-operative learning. The shared platform of projects, presentations, tutorials and discussion on the course website makes sharing and cooperation much easier 
and efficient.

Sustained learning, when we use smart devices in a less structured and opportunistic way. We are usually driven by our own personal curiosity or the need to look up some information, or maybe write a quick email to an expert or a peer, asking a question when the information is not available in any other way but through a smart device. The hyperlinks on the web pages/blogs and links to a variety of recourses on sidebar provide a rich clue for students to do further research and guided self-learning.

Supportive learning, Where smart devices guide learner's progress. Supportive learning helps learners look up their schedules and dates, review and manage progress, and help with time management: The shared Google sheets allow the students to schedule their own presentation and progress, post website links while under the management and supervision of the instructor.

\section{IMPROVING COURSE CONTENT AND DELIVERY}

By implementing the new course delivery platform, we can solve the aforementioned problems in teaching practical media and journalism courses. The new smart learning strategies will integrate all the course content on one platform and make delivery easier, smoother and more effective. The content can be presented in a richer and more systematic way. Lectures can be supported with multimedia content; theories can be explained using easily linked examples. It is easy to update the content and keep a record of any changes and developments. Student works can be easily showcased. Discussions are more engaging and deeper and all the responses can be recorded for future reference. Tutorials can be recorded and retrieved. Students' works, presentations, projects can be recorded, shared and showcased. Peer learning/assessing can be initiated. Evaluation of students' work is more efficient and hassle-free. Project signup is more convenient, flexible and user-friendly. The website is easy to maintain and update. It can keep a good record of the course development and students' projects.

\section{ENHANCING STUDENTS' LEARNING EXPERIENCE}

Course website provides well-designed online multimedia content, rich information on the webpage and blogs, hyperlinks and recourses. The students will be more attracted and engaged in the class, as it provides an immersive audio-visual learning experience. It can help them understand the theoretical concepts and principles, nature creative and critical thinking and encourage them in research and independent learning. Online assessment such as Pollydaddy.com and Quizlet allows the students to see the correct answers once they finished their quiz. The immediate feedback is very helpful in building students' understanding. Learning can happen anywhere and anytime. The content is available on all digital and mobile devices, e.g. smartphones, iPad, and laptops. Tutorial videos can be accessed outside the classroom. More time can be devoted to solving individual and specific problems in the class. It is paperless and more environment-friendly. The digital learning experience prepares the students for the new digital age and future development. Peer learning and evaluation happens when students can see each other's progress and works online through course websites.

\section{CONCLUSION}

Web-based course delivery technology has provided an ideal platform for teaching practical media and journalism courses. The multi-media friendly platform and interactive features of the web fit the content of mass communication courses. The new approach improves course delivery and enhances students learning experience. It encourages the implementation of smart learning pedagogies in the $21^{\text {st }}$ century. With the fast development of technology, the transformation and revolution in teaching and learning is a non-stop process. Be innovative and embrace the new challenges in education.

\section{ACKNOWLEDGMENT}

The authors wish to thank Center for Excellence in Teaching and Learning at United Arab Emirates University for their continuous effort and support in professional development. This paper is based on course transformation projects initiated by the center. The paper is partly funded by UAEU Research Start-up Grant on online journalism (G00001670).

\section{REFERENCES}

[1] M. Koehler and P. Mishra, "What is technological pedagogical content knowledge (TPACK)?" Contemporary Issues in Technology and Teacher Education, vol. 9, no. 1, pp. 60-70, 2009

[2] R. Kimmons, "Online system adoption and K-12 academic outcomes," Journal of Computer Assisted Learning, vol. 31, no. 4, pp. 378-391, 2015.

[3] M. J. Koehler, J. M. Rosenberg, S. Greenhalgh, A. Zellner, and P. Mishra, "Can portfolio-based assessments demonstrate teachers" TPACK?" presented at Society for Information Technology \& Teacher Education International Conference 2014, Jacksonville, FL, USA.

[4] M. J. M. Ferreira, "Intelligent classrooms and smart software: Teaching and learning in today's university," Education and Information Technologies, vol. 17, no. 1, pp. 3-25, 2012.

[5] B. Lin and C. Hsieh, "Web-based teaching and learner control: A research review," Computers \& Education, vol. 37, no. 3, pp. 377-386, 2001.

[6] J. E. Clark, "The digital imperative: Making the case for a 21 st-century pedagogy," Computers and Composition, vol. 27, no. 1, pp. 27-35, 2010 .

[7] Smart Learning Operational Committee UAEU Course Transformation Process, 2rd ed., Center for Excellence in Teaching and Learning (CETL), Unite Arab Emirates University, 2016.

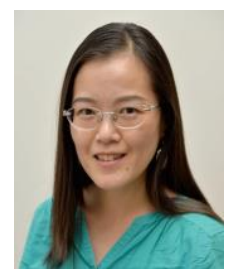

Shujun Jiang is an assistant professor at Mass Communication Department, United Arab Emirates University (UAEU). She serves as faculty fellow at Center for Excellence of Teaching and Learning (CETL) at UAEU. She is a pioneer in the course transformation process initiated by CETL and chairing College Smart Teaching and Learning Committee at UAEU.

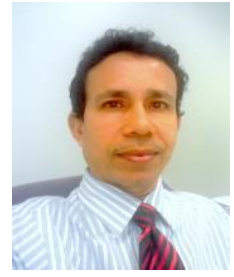

Ali Rafeeq is an assistant professor at Mass Communication Department, United Arab Emirates University (UAEU). He is an active participant in the course transformation process. 